\title{
Effect of the COVID-19 global pandemic on tourists' preferences and marketing mix of accommodation facilities - case study from Czech Republic
}

\author{
Radim Dušek ${ }^{1, *}$ and Nikola Sagapova ${ }^{1}$ \\ ${ }^{1}$ Institute of Technology and Business in České Budějovice, Faculty of Corporate Strategy, \\ Department of Tourism and Marketing, Nemanická 436/7, České Budějovice, Czech Republic
}

\begin{abstract}
Research background: Two related effects of the COVID-19 global pandemic on tourism and hospitality in the Czech Republic are already evident for the upcoming summer months. In the first place, it is the effect on the Czech tourists' preferences. The pandemic forced them to reconsider their plans and, as a result, it is evident that more tourists will spend summer only in the Czech Republic. This change in preferences is connected with a second effect, concerning the strategies of the domestic accommodation facilities - their managers should adapt marketing mix to meet the demand of Czech clients, because unlike the previous years, these tourists will become their main target group.

Purpose of the article: The aim of the paper is to identify the preferences for summer holiday in 2020 of the Czech tourists who have decided to spend summer holiday only in the Czech Republic because of the COVID19 global pandemic as well as to find out their wants in terms of accommodation facilities' marketing mix.

Methods: During spring 2020, a survey of 637 respondents was conducted to determine the preferences of the Czech tourists for summer holiday in 2020. This paper is focused on the analysis of data from respondents who decided to spend this year's summer holiday only in the Czech Republic (a total of 202 respondents).

Findings \& Value added: Based on the results, we will define findings for accommodation facilities regarding the possible update of marketing mix to meet the actual demand of Czech tourists.
\end{abstract}

Keywords: COVID-19 global pandemic; tourists' preferences; marketing mix; accommodation facilities; Czech Republic

JEL Classification: $M 31 ; L 83 ; Z 32$

\footnotetext{
* Corresponding author: $\underline{\text { dusek } @ \text { mail.vstecb.cz }}$
} 


\section{Introduction}

The COVID-19 has been recognized as one of the most impactful events of the $21^{\text {st }}$ century [1]. It has caused significant changes in economic activities, as many of them have been shut down in order to protect people [2].

Tourism presents social and cultural phenomena [3] with considerable economic impact affecting income, wealth and employment in a given geographic area [4]. In some destinations, tourism presents the only mean of economic growth [5]. The impact of COVID-19 on tourism is tremendous, as the borders were closed, air fleets and cruise vessels stayed grounded and docked, accommodation establishments and out-of-home dining were shut down [1]. The right to travel and enjoy hospitality facilities has been restricted in way which was unprecedented since the world wars [6]. This situation has led to enormous revenue loss for tourism enterprises due to restrictions on movement [7], amplified by high uncertainty related to global travel restrictions [8]. The coronavirus outbreak also alters images of particular destinations, and may harm especially those suffering from high infection rates, while in contrast, can be beneficial for some other destinations [1]. The COVID-19 heavily impacted the international travel, but also tourism demand, and hospitality industry as whole [9]. The desire to travel by air has dropped by about $30 \%$ in Europe and the Americas, $50 \%$ in Asia, and intention to travel has dropped additional 10-20\% [10]. The countries reliant on tourism will be more affected by the impacts of this crisis [11].

Yet, there is hope, that this pandemic creates an opportunity and impulse to reshape tourism into more sustainable, inclusive and caring [12]. The mobility restrictions have forced many to embrace hyperlocal approaches to travel in nearby nature which can be tagged as low-carbon and human-scaled travelling that provides many kinds of social, economic and environmental benefits [13]. The other author argued that there are several disruptive influences important for a transition of tourism towards more sustainable travel practices. Amongst these key factors are not only health and safety concerns, such as in case of COVID-19 pandemic, but also environmental crisis, or periodic chaos in markets and economies, as well as new technologies [14].

\section{Methods}

The aim of the paper is to identify the preferences for summer holiday in 2020 of the Czech tourists who have decided to spend summer holiday only in the Czech Republic because of the COVID-19 global pandemic as well as to find out their wants and expectations in terms of accommodation facilities' marketing mix. An extensive survey was carried out to determine the preferences and attitudes of inhabitants of the Czech Republic towards travelling during the COVID-19 season. The survey was carried out on a random sample of respondents. Data were collected with help of students and employees of VŠTE. During spring 2020, a survey with a total of 637 respondents older than 18 years was conducted to determine the preferences of the Czech tourists for summer holiday in 2020. The survey questionnaire consisted of 24 mostly closed-ended questions dealing with different aspects of travel desire, intentions, preferences and attitudes during this unusual tourist season. The software Statistica v. 13 was used to evaluate the data.

This paper is focused on the analysis of data from respondents who decided to spend this year's summer holiday solely in the Czech Republic after the restrictions on movement (a total of 202 respondents out of 637). It means although having random sample of respondents, for this particular paper the selective sample of respondents was used. The Table 1 below provides an overview of the socio-demographic characteristics of the sample. 
Table 1. Socio-demographic characteristics of the sample $(n=202)$

\begin{tabular}{|l|c|c|c|c|c|c|}
\hline Gender & \multicolumn{4}{|c|}{ Male (48) } & \multicolumn{3}{c|}{ Female (154) } \\
\hline Age & \multicolumn{2}{|c|}{ 19-26 (110) } & \multicolumn{2}{|c|}{$27-40(55)$} & $41-55(31)$ & \multicolumn{2}{c|}{$56-65(6)$} \\
\hline Education & \multicolumn{3}{|c|}{ Primary (1) } & \multicolumn{2}{c|}{ Secondary (130) } & \multicolumn{2}{c|}{ Tertiary (71) } \\
\hline $\begin{array}{l}\text { Social } \\
\text { status }\end{array}$ & $\begin{array}{c}\text { Student } \\
(75)\end{array}$ & $\begin{array}{c}\text { Employed } \\
(110)\end{array}$ & $\begin{array}{c}\text { Self- } \\
\text { employed } \\
(7)\end{array}$ & $\begin{array}{c}\text { Unemployed } \\
(1)\end{array}$ & $\begin{array}{c}\text { Maternity } \\
\text { Leave (8) }\end{array}$ & $\begin{array}{c}\text { Retired } \\
(1)\end{array}$ \\
\hline $\begin{array}{l}\text { Household } \\
\text { income }\end{array}$ & Below average (32) & $\begin{array}{c}\text { Average } \\
(139)\end{array}$ & Above average (29) & Undefined (2) \\
\hline
\end{tabular}

\section{Results}

\subsection{Travel preferences and intentions}

The acquired data enabled us to register a significant shift in the preferences and travel intentions during summer season 2020. This shift towards domestic tourism was influenced by the COVID-19 pandemic and related restrictions on movement. More than $62 \%$ of respondents originally planned to enjoy their summer at least partially abroad. Most of them intended to combine domestic and international travel, but more than $16 \%$ desired to enjoy solely international travel as shown in Figure 1.

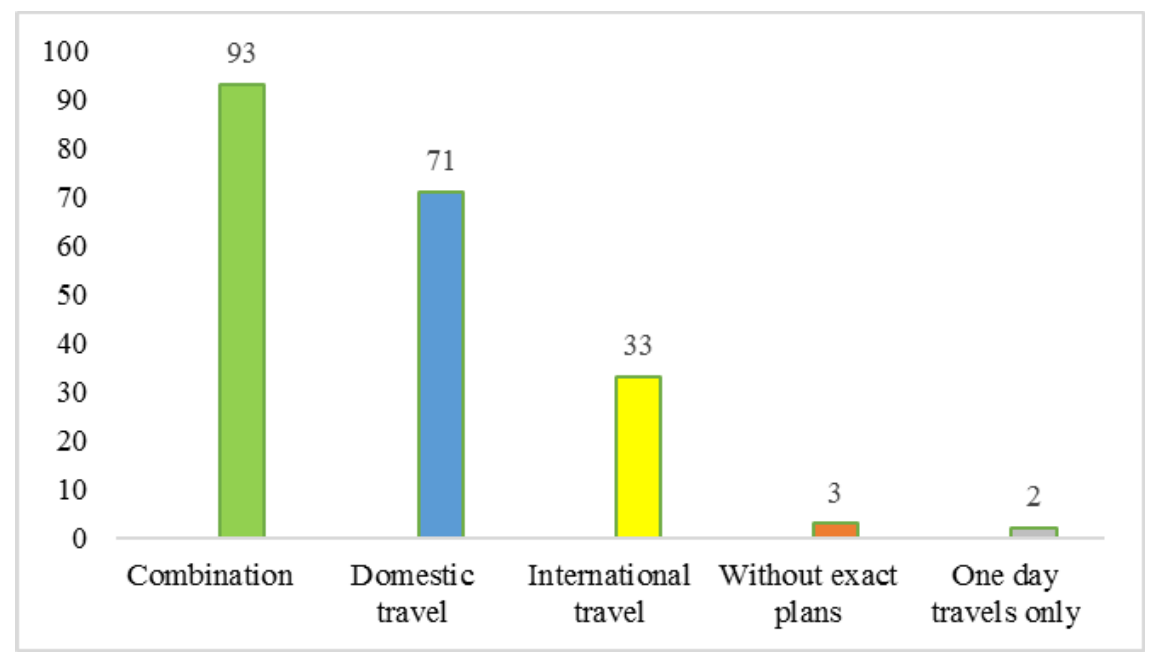

Fig. 1. Respondents' travel intentions before COVID-19 pandemic $(n=202)$

There were no statistically significant differences between groups of men and women, although differences not far from the level of significance were discovered (Pearson chisquare $=10.17 ; \mathrm{p}=0.07$ ), where women intended to combine domestic and international travel more preferably, while men preferred domestic travel only. There were no statistically significant differences between the groups based on age (Pearson chi-square = $11.1 ; \mathrm{p}=0.75$ ), social status (Pearson chi-square $=23.12 ; \mathrm{p}=0.57$ ), or household income (Pearson chi-square $=12.6 ; \mathrm{p}=0.24$ ).

As for the length of the intended stay in Czech republic after the COVID-19 outbreak, counted as a sum of all intended stays, the biggest portion (36\%) of respondents plans to spend two summer weeks by domestic travel, another $24 \%$ of respondents wants to spend just one week by domestic travel, $13 \%$ of respondents intends to enjoy one and half week, 
while $8 \%$ thinks about spending even less than one week by domestic travel within the Czech republic. As for the longer stays, $8 \%$ of respondents would love to travel for three weeks, $6 \%$ of respondents two and half weeks, while only $5 \%$ of respondents more than three weeks.

\subsection{Preferred Czech places and destinations}

The preferences within the dimension linked with local attractiveness are as follows: most of respondents intend to enjoy natural sites and activities such as hiking, biking, swimming and relaxation $(42 \%)$, the next most preferred places are smaller towns with historical centers, castles and other cultural heritage and natural sites in the surroundings $(28 \%)$, rural sites with natural and cultural heritage sites in the surroundings $(27 \%)$, while bigger cities are preferred for the opportunities of social life, shopping, out-of-home dinning places and cultural sites (3\%).

Regarding the destinations the most desired ones are Moravia, especially the South Moravia well-known for its vineyards, and South Bohemia, especially the National Park Bohemian Forest. The desire to visit protected areas within Czech Republic shall be mentioned. Amongst these our respondents intended to visit national parks (NP Bohemia Forest, Karkonosze NP, NP Bohemia Switzerlad and Podyjí NP), protected landscape areas (Broumovsko, Beskydy, Jeseníky, Pálava, Český ráj, Jizerské hory, Kokořínsko, Třeboňsko, Novohradské hory, Orlické hory and Železné hory), national nature preserves (Adršpach and Králický Sněžník), UNESCO sites and towns with UNESCO sites (Lednicko-Valtický areál, Kroměříž, Praha, Kutná Hora, Olomouc, Brno).

Český Krumlov, one of the Czech UNESCO sites, was not mentioned as a desired place to visit during summer by any of the Czech respondents, who, as we found out, perceive Český Krumlov as too expensive, too overcrowded by foreigners, and too tourists-oriented destination, although they appreciate its historical and architectonical values. Many of them mentioned that they would not choose this town for the summer holidays as far as they already visited it, or live nearby, so they can come anytime. Just few respondents were willing to visit spa towns, or other urban sites except those with cultural heritage listed in UNESCO.

\subsection{Marketing mix update options}

Considering the marketing mix (4 Ps: product, price, place and promotion) recommendations relevant for destinations and accommodation facilities, it can be concluded that there is desire for the expansion of the "product" by services and tourism packages offered. Only $20 \%$ of respondents declared that these services and packages would not motivate or affect the choice of the destination and accommodation, but some of them mentioned, that they would appreciate if the site they had chosen had offered facilities and equipment for sport activities, horse rides, wellness, massages, degustation of wine, or other local products, or a romantic dinner. These offers would motivate the other $80 \%$ of respondents when choosing the destination and accommodation, as well as many of them would appreciate free tickets to museums, castles, or other cultural sites in the surroundings. As for the minimum requirements for the equipment of room or accommodation facility, own bathroom is demanded by $76 \%$ of our respondents, free Wi-Fi is demanded by $65 \%$ of them, own parking by $52 \%$, and restaurant is demanded by $42 \%$. A fireplace or a place for barbecue is required by $33 \%$ of respondents, while swimming pool is a must for nearly $31 \%$ of them. Television in the room, or own kitchen is required similarly by $27 \%$ of potential Czech tourists. A total of $15 \%$ respondents 
required the opportunity to be accommodated with own pet. Whirlpool in the accommodation facility is important for $12 \%$ of them.

As for the "price", the modus value is 500-999 CZK/night (48\% respondents). Regarding the "place", we might imply not only the locations (in wider context whole destinations), or inventory (here we mentioned the minimum requirements), but also the types of accommodation or even the channels that make the product available to consumers. As for the preferred types of accommodation, most of respondents intends to stay in smaller pension or accommodation in a private residence with capacity up to 10 guests $(54 \%$ ), other types are less popular (larger pension $-17 \%$, hotel 3 stars or more $-13 \%$, camping sites $-7 \%$, hotel 3 stars or less $-4 \%$, only several respondents prefer other types such as spa resort, cabin, own van, sleeping in own tent in nature or sleeping in the open air).

In terms of "promotion" that refers to different types and channels of marketing communications with potential customers, most of Czechs choose their accommodation through Booking.com (51 \%). They also use other channels and web sites such as Google (42\%), own web sites of the accommodation facilities (32\%), discount portals (28\%), Trivago.cz (13\%), information portals of the towns (11\%), Tripadvisor.com (7 \%), Hotel.cz (9 \%), others use Airbnb.cz, Mapy.cz, Park4Night, Spa.cz, own experience or experiences of people they know.

\section{Discussion}

The long-term effects of the COVID-19 pandemic not only on tourism are yet to come, however at least a short-term shift towards domestic travel was observed. We can expect some temporary shifts due to border lockdowns and health concerns especially in connection with China, but also higher costs of transport and logistics services [15]. Some authors reported strong domestic tourism in the USA and China triggered by the restrictions and bans on global and domestic travel, whereas not so strong domestic tourism in case of EU, although they link European countries highly infected by COVID-19 with economic loss resulting from the tourism collapse [16]. On the other hand, the COVID-19 global crisis can provide an opportunity to transform tourism into more socialized form, where the rights and interests of local communities and people matter, therefore as an impulse to set a social and ecological justice for tourism after COVID-19 with respect to social and ecological limits of the planet [17]. The desire for visiting protected natural areas was reported in this paper, but this higher demand, when realized, might become a threat - or an opportunity - for protected areas management, moreover if it comes to the rules violation. The possible environmentally positive effects are also mentioned. This global pandemic and the lockdown experience may lead people a shift towards a higher valuation of environmental assets, and therefore might play a role in tackling of the climate change and biodiversity loss [18]. Other authors highlight the effect of restricted movement and reduced economic activity as beneficial for some ways of biodiversity conservation, but in Africa, they foresee strongly negative net conservation impacts of COVID-19 because of reduced funding restrictions on the operation agencies, and increased human threats to nature [19]. However, the increased visitor attraction in protecting worthy areas that are famous might endanger the environment and locals' acceptance [20], but when destinations become overcrowded, the quality of the tourist experience declines [21]. This is also the case of Český Krumlov, which is an UNESCO site. Anyway, increased traffic in protected natural areas, especially in national parks with barely altered nature and little human impact, shall result in monitoring of the state of environment, tourist traffic size and trends and impact of tourism on these location in order to develop and implement an efficient 
management to conserve the values of the natural sites, modify conservation plans, and enable sustainable tourism [22].

\section{Conclusions}

The aim of the paper was to identify the preferences for summer holiday in 2020 of the Czech tourists who have decided to spend summer holiday only in the Czech Republic because of the COVID-19 global pandemic as well as to find out their wants and expectations in terms of accommodation facilities' marketing mix. Data obtained from 202 respondents enabled us to register a significant shift in the preferences and travel intentions during this year's summer season due to the COVID-19 pandemic and related restrictions. More than $62 \%$ of respondents originally planned to enjoy their summer at least partially abroad. Most of them intended to combine domestic and international travel, but more than $16 \%$ desired to enjoy solely international travelling, but eventually they all decided for domestic holiday. As for the summer 2020 preferences within Czech Republic, most of respondents intend to enjoy natural sites and activities such as hiking, biking, swimming and relaxation, the next most preferred places will be smaller towns with historical centers, castles and other cultural heritage and natural sites. Regarding the destinations the most desired ones will be Moravia Region, especially the South Moravia that is well-known for its vineyards, and South Bohemia Region, especially the National Park Bohemian Forest. Considering the marketing mix recommendations relevant for destinations and accommodation facilities, it can be concluded that there is great demand for the expansion of the typically offered "product" with additional services that will be included in the price of accommodation, for example wellness, degustation of wine or local products, equipment for sport activities or free tickets for sights and attractions in a particular destination.

This study was supported by grant IGS 8110-001 from the Institute of Technology and Business in České Budějovice, Faculty of Corporate Strategy.

\section{References}

1. Zenker, S., Kock, F. (2020). The coronavirus pandemic - A critical discussion of a tourism research agenda. Tourism Management, 81, 104164.

2. Bashir, M.F., Ma, B.J., Shahzad, L. (2020). A brief review of socio-economic and environmental impact of Covid-19. Air Quality, Atmosphere and Health, n/a(n/a).

3. Harrison, D. (2007). Towards Developing a Framework for Analysing Tourism Phenomena: A Discussion. Current Issues in Tourism, 10(1), 61-86.

4. Frechtling, D.C. (1994). Assessing the economic impacts of travel and tourismIntroduction to travel economic impact estimation. In Richie, J.R.B., Goeldner, Ch.R. (Eds.). Travel, Tourism and Hospitality Research: A Handbook for Managers and Researhers. New York: John Wiley \& Sons.

5. Pratt, S. (2015). The economic impact of tourism in SIDS. Annals of Tourism Research, 52, 148-160.

6. Baum, T., Hai, N.T.T. (2020). Hospitality, tourism, human rights and the impact of COVID-19. International Journal of Contemporary Hospitality Management, 32(7), 2397-2407. 
7. Williams, C.C. (2020). Impacts of the coronavirus pandemic on Europe's tourism industry: Addressing tourism enterprises and workers in the undeclared economy. International Journal of Tourism Research, $\mathrm{n} / \mathrm{a}(\mathrm{n} / \mathrm{a})$.

8. Gössling, S., Scott, D., Hall, C.M. (2020). Pandemics, tourism and global change: a rapid assessment of COVID-19. Journal of Sustainable Tourism, 29(1), 1-20.

9. Chang, CH.-L., McAleer, M., Ramos, V. (2020). A Charter for Sustainable Tourism after COVID-19. Sustainability, 12(9), 3671.

10. Gallego, I., Font, X. (2020). Changes in air passenger demand as a result of the COVID-19 crisis: using Big Data to inform tourism policy. Journal of Sustainable Tourism, n/a(n/a).

11. Fernandes, N. (2020). Economic Effects of Coronavirus Outbreak (COVID-19) on the World Economy. SSRN Electronic Journal.

12. Cheer, J.M. (2020). Human flourishing, tourism transformation and COVID-19: a conceptual touchstone. Tourism Geographies, 22(3), 514-524.

13. Mackenzie, S.H., Goodnow, J. (2020). Adventure in the Age of COVID-19: Embracing Microadventures and Locavism in a Post-Pandemic World. Leisure Sciences, n/a(n/a).

14. Fennell, D.A. (2020). Technology and the sustainable tourist in the new age of disruption. Journal of Sustainable Tourism, n/a(n/a).

15. Barua, S. (2020). Understanding Coronanomics: The economic implications of the coronavirus (COVID-19) pandemic. SSRN Electronic Journal.

16. Islam, M.M., Fatama, F. (2020). Covid-19 and Sustainable Tourism : Macroeconomic Effect and Policy Comparison among Europe, the USA and China Assian Business Review, 10(1), 53-60.

17. Higgins-Desbiolles, F. (2020). Socialising tourism for social and ecological justice after COVID-19. Tourism Geographies, 22(3), 610-623.

18. Helm, D. (2020). The Environmental Impacts of the Coronavirus. Environmental and Resource Economics, 76, 21-38.

19. Lindsey, P., Allan, J., Brehony, P., Dickman A. Robson, A., Begg, C., Bhammar, H., Blanken, L., Breuer, T., Fitzgerald, K., Flyman, M., Gandiwa, P., Giva, N., Kaelo, D., Nampindo, S., Nyambe, N., Steiner, K., Parker, A., Roe, D., Thomson, P,, Trimble, M., Caron A., Tyrell, P. (2020). Conserving Africa's wildlife and wildlands through the COVID-19 crisis and beyond. Nature Ecology \& Evolution, 4(10), 1300-1310.

20. Ryan, J., Silvanto, S. (2009). The World Heritage Site List: The Making and Management of a Brand. Place Branding and Public Diplomacy, 5(4), 290-300.

21. Bushell, R., Staiff, R., Eagles, P.F.J. (2007). Tourism and protected areas: benefits beyond boundaries. In Bushell, R., Eagles, P.F.J. (Eds.) Tourism and Protected Areas: Benefits Beyond Boundaries. United Kingdom: CABI.

22. Olesniewicz, P., Pytel, S., Markiewicz-Patkowska, J., Szromek, A.R., Jandova, S. (2020). A Model of the Sustainable Management of the Natural Environment in National Parks - A Case Study of National Parks in Poland. Sustainability, 12(7), 2704. 